\title{
TiC-TiN-Mo $\mathrm{M}_{2} \mathrm{C}-\mathrm{Cr}_{3} \mathrm{C}_{2}$ 系複合セラミックスの強䩚化現象
}

\author{
(侏)不二越 蜂須賀武治
}

Takeji Hachisuka: Toughening Phenomena in $\mathrm{TiC}-\mathrm{TiN}-\mathrm{Ho}_{2} \mathrm{C}-\mathrm{Cr}_{3} \mathrm{C}_{2}$ Ceramic Composite.

It had been confirmed in the previous work that $70 \% \mathrm{TiC}-15 \% \mathrm{TiN}-7 \% \mathrm{Mo}_{2} \mathrm{C}-8 \% \mathrm{Cr}_{3} \mathrm{C}_{2}$ ceramic composite showed distinguished sinterability similar to liquid phase sintering alloys. That is to say, the complete dense bodies of the composite can obtain by means of sintering at $1623 \mathrm{~K}$. Present study was undertaken to reveal the effect of microstructure on properties of the dense ceramic composite in relation to sintering temperature up to $1873 \mathrm{~K}$.

The ceramic composites were strengthened, toughened and hardened with accompanied grain growth according to rise of sintering temperature. Bending strength, fracture toughness and Vickers hardness reached the values of about $780 \mathrm{MPa}, 4.65 \mathrm{MPa} \cdot \mathrm{m}^{1 / 2}$ and $24.0 \mathrm{GPa}$ respectively in the specimen sintered at $1823 \mathrm{~K}$.

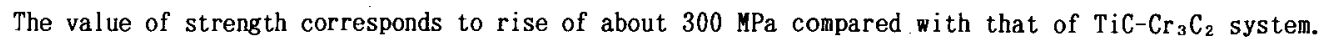

It was confirmed in fracture test that the composites have the characteristics of easy branching property of cracks and of slow velocity in crack propagation, which resulted remaining of many branched cracks in the specimens after fracture.

Morphology of cracks in fractured specimens elucidated multi-toughening phenomena in the ceramic composite, comprising branching and deflection of cracks and micro-cracking. And, the rise of strength was presumed due to $\mathrm{R}$-curve behaviour.

(Received July 6,1990)

\section{I 緒 言}

$\mathrm{Cr}_{3} \mathrm{C}_{2}$ との復合化”は、TiCの焼結性を改善し無加圧焼 結による完全綊密化を可能にしたが、同時に锛結過程で 生成する低次Cr炭化物が金属不純物を固溶·吸収し、高温 特性に及ぼす悪影響 $\left.{ }^{2}, 3\right)$ も除去する。この両効果は、立 方晶高温相 $\mathrm{CrC}$ を溶質物質とする $\mathrm{Cr}_{3} \mathrm{C}_{2}$ のTiCへの易固溶 機構" に基つく。一方、抗折強度は550MPa程度であり、 構造材料セラミックスの強度として十分でない。しかし 粒成長が強度低下をもたらす”ため、 $\mathrm{TiC}-\mathrm{Cr}_{3} \mathrm{C}_{2}$ 複合系で の強靶化は期待しがたい。

そこで著者は、切削工具開発のための強物化手段とし てTiC-Cr $\mathrm{C}_{3} \mathrm{C}_{2}$ 系に対する $\mathrm{Mo}_{2} \mathrm{C} と \mathrm{TiN}$ との同時添加を試み、 まずその娔絓挙動 ${ }^{5)}$ を俟討した。その結果、このTiC-TiN$\mathrm{Mo}_{2} \mathrm{C}-\mathrm{Cr}_{3} \mathrm{C}_{2}$ 多元系複合セラミックスは金属不純物に対す る固溶・吸収効果を維持したまま、娔結性がさらに向上し て1623K娔結で完全に概密化し、1873K狫結まで良好な緅 密度を維持することが確認された。また本多元系では、

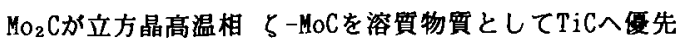
固溶し $\left(\mathrm{Ti} \cdot \mathrm{Mo}_{\mathrm{o}}\right) \mathrm{C}$ 固溶体を形成するが、この $\left(\mathrm{Ti} \cdot \mathrm{Mo}_{\mathrm{O}}\right) \mathrm{C}$ 固溶 体の固溶促進効果に基づく $\mathrm{T}$ iNの急速な固溶反応が福 化の主駆動力として機能することによって、焼結性が改 善されるという易嫃結機構も明らかとなった。

他方、このTiC-TiN-MO ${ }_{2} \mathrm{C}-\mathrm{Cr}_{3} \mathrm{C}_{2}$ 多元系椱合セラミック スは、緻密化後の高温锛結により粒成長を伴い強靶化す
ることが確諗された。本報ではこの強䩓化について、主 として現象面からの㛟討を行なった。

\section{II 試料および実娩方法}

陚料は前報 5 で調製した4元系複合セラミックスであ る。その配合組成はmass \%で $70 \% \mathrm{TiC}-15 \% \mathrm{TiN}-7 \% \mathrm{Mo}_{2} \mathrm{C}$ $8 \% \mathrm{Cr}_{3} \mathrm{C}_{2}$ であり、不純物として䄪 $0.8 \mathrm{msss} \%$ の鉄族金属 を含有する。実験には抗折力試渙片を用い、锛結温度と の関係で強勒化現象を検討した。各試片は $25 \sim 100 \mathrm{~N} / \mathrm{m}^{2}$ (2 8 $\left.\times 10^{-1} \mathrm{mmHg}\right)$ の弱浸炭性妒内発生カス需囲気下で、 1623 1873Kの所定温度に7.2ks保持して焼結した。各娔 結温度での試片数は8本である。これらの焼結試片はいず れも完全維密体 ${ }^{5)}$ であり、本質的なポアは存在しない。 試片は超硬合金の抗折力試疆法に準拠して $24 \times 8 \times 4 \mathrm{~mm} の$ 寸 法にダイヤモンド砥石で研削し、抗折力陚鈋に供した。 クロスヘッド速度は $3.3 \times 10^{-6} \mathrm{~m} / \mathrm{s}(0.2 \mathrm{~mm} / \mathrm{min})$ とした。

破断後の試片はHRA硬度を测定後、ラッピングを行なっ て荷重294Nでビッカース硬度とIF法による破缐靶性を测 定した。破壊靿性は Evans and Charles $の$ 関係式 ${ }^{6)}$ を用 いて算出した。

本多元系複合セラミックスは抗折力試㬇で影著な奄裂 分蚑(branching)を起すが、龟裂伝播速度が遅いため、破 断後の試片に分忮渑裂が残存する。そのため、この残存 
分岐亀裂により破壤機構の直接観察ができる。分岐亀裂 に関しては光学䫒微鏡とSEM像とで詳細に調査し、强勒化 現象を哂裂形態から追求した。光顕での分岐亀裂観察に は微細な亀裂を鮮明化するため、軽い糜食を行なった。

\section{III 実娩 結 果}

焼結温度と抗折力ならびに破壊勒性の関係をFig. 1 に 示す。本試料は $\mathrm{TiC}-\mathrm{Cr}_{3} \mathrm{C}_{2}$ 系と異なり、縀密化後の高温娔 結で強度は上昇し、1823K䂏結で784MPaに達した。これは、 アルミナ系セラミックエ具とほほ同等の強度である。併 示したTiC- $\mathrm{Cr}_{3} \mathrm{C}_{2}$ 系 ${ }^{1)}$ との対比から明らかなように、 $\mathrm{Mo}_{2} \mathrm{C}$ とTiNとの同時添加で強度は約300MPa向上した。なお抗折 力測定時に、特に高温嬈結試片では破断前に負荷速度が 明らかに低下する現象がしばしば確認された。これは、 まず安定破壤がかなり広範囲に進行し、その後不安定破 壤へ移行することを示唆する。破壤勒性も高温㜣結で上 其した。なお Photo. 1 に示すように、圧痕亀裂は主とし て粒界を通り、高温焼結試片では粒成長に依存して渑裂 の偏向(deflection)が增大する傾向がみられた。しかし、 圧痕星裂に渑裂分岐は認められなかった。

焼結温度と破面の関係をPhoto. 2 に示す。焼結温度の 上昇はかなり顕著な粒成長をもたらすが、本試料では高 温赎結試片でも粒界破壤の比率がわめて大きい。これ は、粒成長に伴い粒界破壤からほほ完全な粒内破壤へと 遷移して強度低下をもたらした $\mathrm{TiC}-\mathrm{Cr}_{3} \mathrm{C}_{2}$ 系の破壤挙動
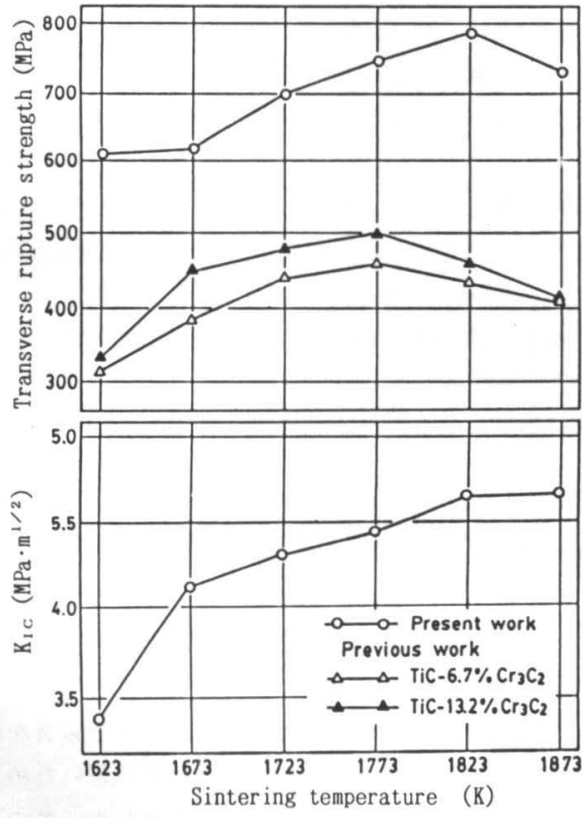

Fig. 1 Transverse rupture strength and fracture toughness of the dense $\mathrm{TiC}-\mathrm{TiN}-\mathrm{Mo}_{2} \mathrm{C}-\mathrm{Cr}_{3} \mathrm{C}_{2}$ ceramic composite as a function of sintering temperature.
とは本質的に異なる。この高温焼結試片における粒界破 壤の一因には、亀裂伝播速度が遅いことの寄与 ${ }^{7}$ が考え られる。

焼結温度と硬度の関係をFig. 2 に示す。一般にきわめ て高い硬度を示したが、HRAとHVとでは举動が異なる。す なわち、HRAの焼結温度依存性は比敕的小さく、1723K以 上の高温焼結でわずかな低下傾向を示した。一方、HVは 高温焼結で明らかに上昇し、1823Kで HV:24.0GPaに達し た。この硬度は、ダイヤモンドおよびCBN焼結体以外の切 削工具材料では最高の値である。また、HVの挙動は抗折 力の変化と対応する。

Fig. 3 は種々の多元系複合セラミックスについて、両 硬度の関係を求めた結果である。 HRA94. 5 以上では直線 関係が成立しなくなる。また、このような高硬度材では 特に圧子が損傷し易いか、、きわめて微細な圧子のチッピ ングでHRAは低下する。結局、本実験でのHRA測定結果は 信頼性に欠けるものと判断した。

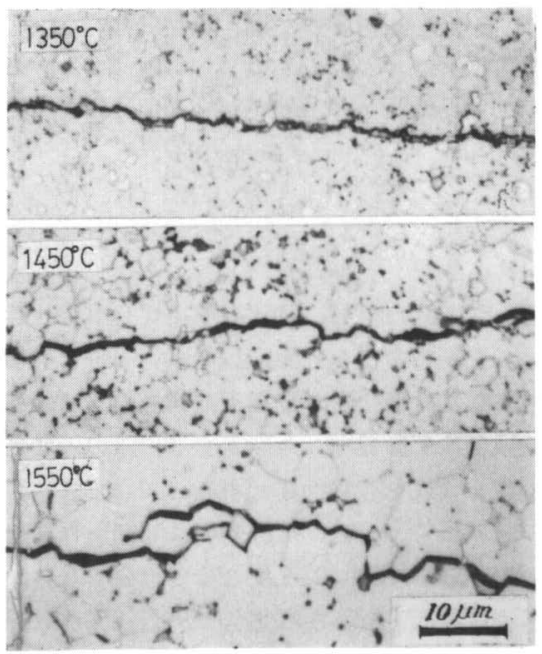

Photo. 1 Crack deflection profile of Vickers indentation cracks in specimens sintered at noted temperatures. Branching of cracks was not observed.

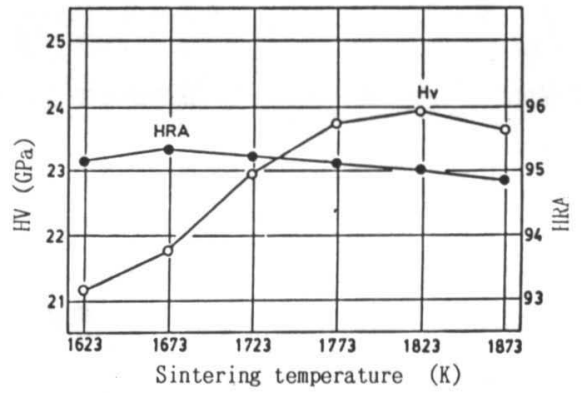

Fig. 2 Hardness in HRA and HV of the ceramic composite as a function of sintering temperature. 


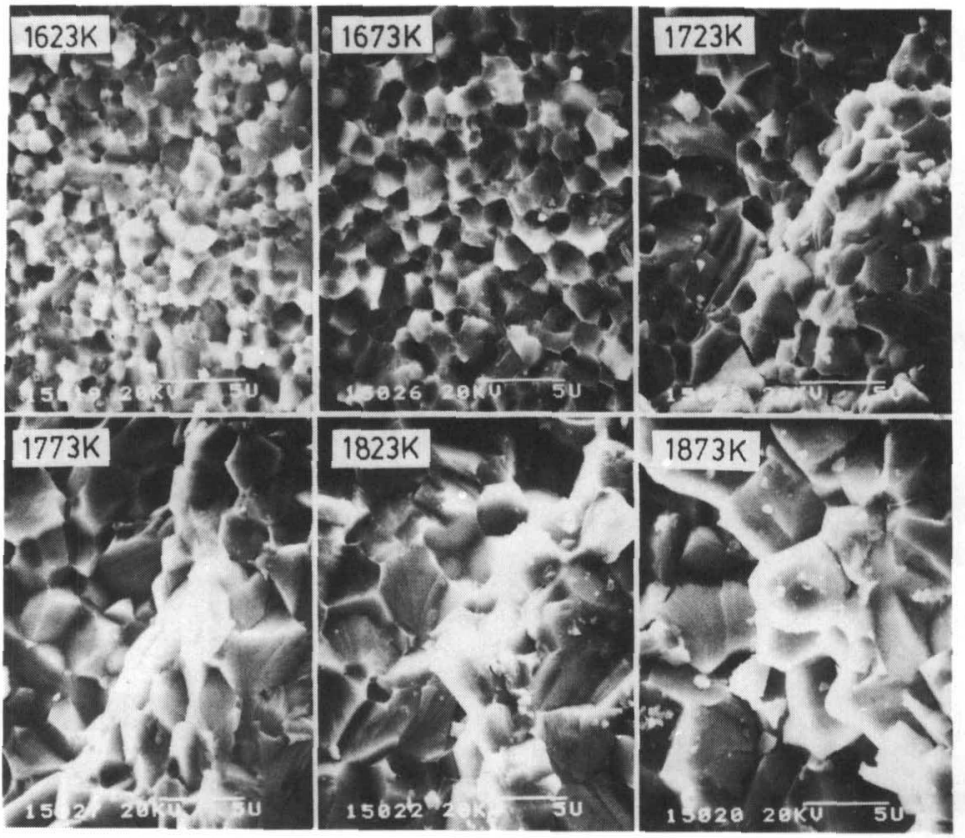

Photo.2 Scanning electron fractographies of the ceramic composite tested at room temperature in three-point bending as a function of sintering temperature. Fracture mode is predominantly intergranular even in the specimens sintered at higher temperatures.

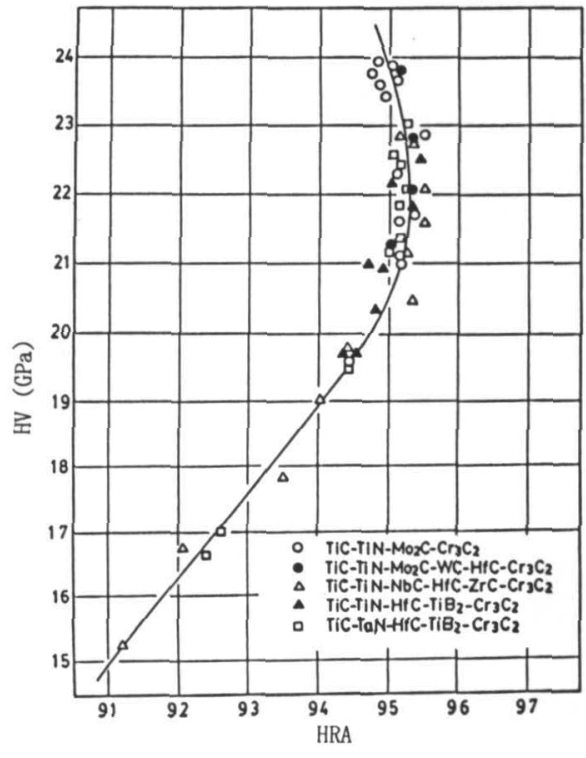

Fig. 3 Correlation between HRA and HV in various $\mathrm{TiC}-\mathrm{Cr}_{3} \mathrm{C}_{2}$ base ceramic composites in high hardness range.

本試料は抗折力試験での破壤過程で顕著な亀裂分岐を 起し、この分岐渑裂が破断後に多数残存することが確認 された。試片表面で観察されるその状況をFig. 4 で説明

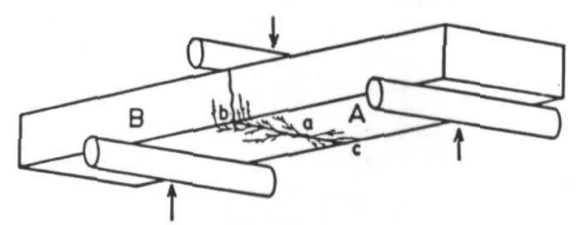

Fig. 4 Schematic drawing concerning occurrence of crack branching in bending fracture test.

する。張力側 $(A$ 面)の破壊起点 a で発生した主舶裂が両 端部 b および c ヘ伝播する過程で、龟裂分岐が起る。 この分岐亀裂も、分岐を起しながら両端部に向って扇状 に伝播する。ただし、破壤起点が端部近傍の場合は、他 端に向け同様の分岐を伴って伝播する。一般に破壊起点 近傍で発生した分岐亀裂は破断時までに端部へ到達しな いか、端部近傍で発生した分岐渑裂は、端部へ到達後、 側面(B面)を圧縮側 (上面)に向け伸展する。B面の分岐渑 裂の多くは、破断時までに上面にまで達しない。このよ うにして、破断後のA面およびB面に多数の分岐渑裂が残 存する。この分岐皂裂の残存は、本試料の亀裂伝播速度 が遅く、安定破壞領域が大きいことを立証する現象であ る。これは、既述の破断前の負荷速度の低下現象と対応 する。

破断後の分串㫣裂の一例を Photo. 3 および Photo. 4 


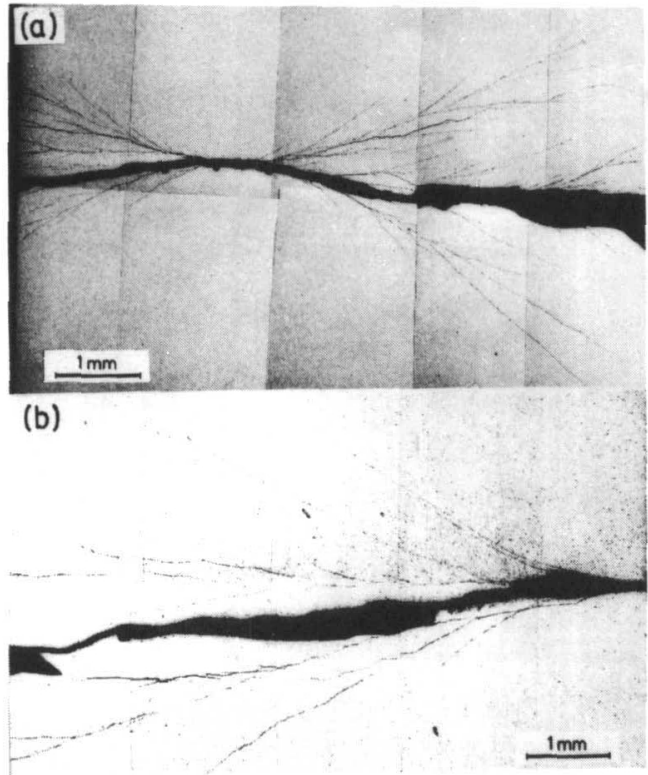

Photo. 3 Morphologies of branched cracks in A plane remained after fracture test. The photographs show the cases that fracture began at the center (a) and in the vicinity of the end (b) of the plane, respectively.

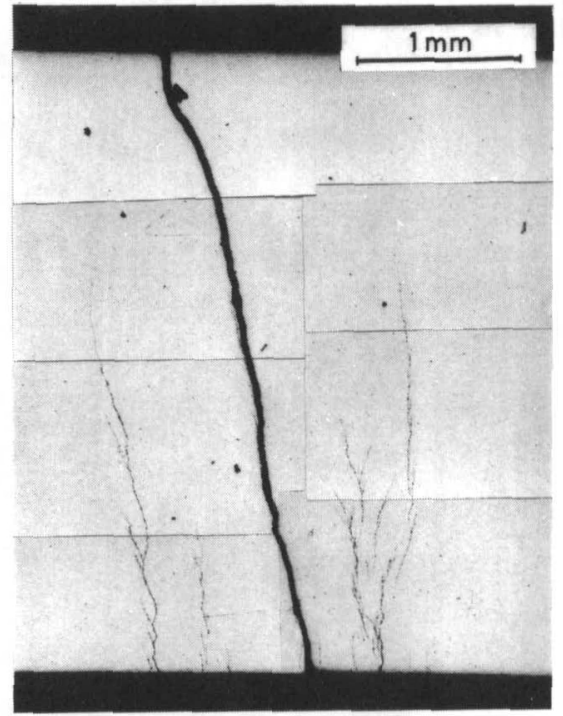

Photo.4 Motrphology of branched cracks in B plane remained after fracture test.

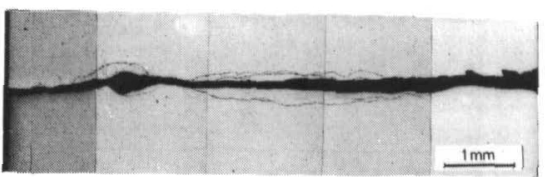

Photo. 5 Remained cracks in upper plane after fracture test, occurred due to compressive stress.
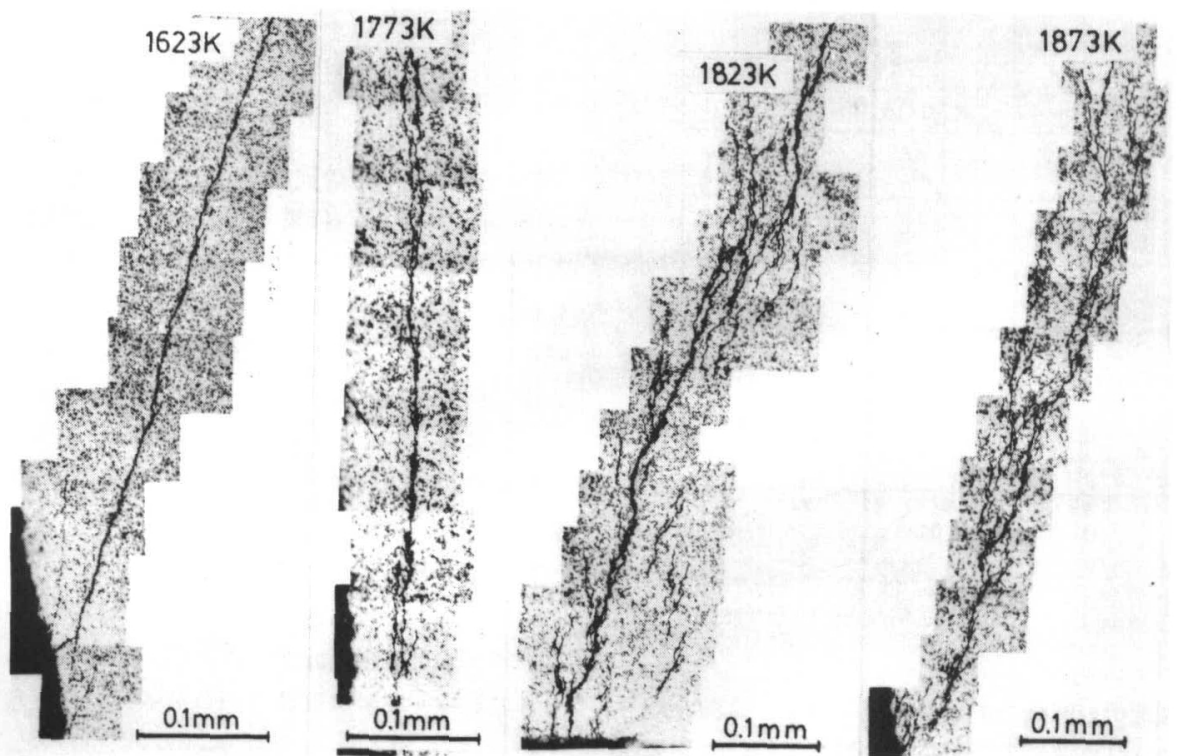

Photo. 6 Morphologies of remained branched cracks in relation to sintering temperatures. 
に示す。それぞれA面およびB面での残存状況である。 Photo. 3 の(a)は試片中央、(b)は端部近傍で破壊が開始 した例である。Photo. 5 は試片上面に残存した圧縮亀裂 である。

すべての焼結温度で分岐渑裂の残存が観察された。し かしこの分岐の発生は、緻密化完了時点すなわち1623K焼 結試片では少なく、高温焼結での明らかな増加が確認さ れた。その状況を Photo. 6 に示す。Photo. 7 は高温焼 結試片における顕著な龟裂の分岐状況を示した光顕写真 である。分岐と同時に、亀裂の偏向ならびに副龟裂の発 生も観察される。Photo. 8 の高倍率SEM像では、粒界破壤 の様相が確認される。また高温焼結試片では、マイクロ クラックの発生も確認された。Photo. 9 に分岐近傍で観 察されたマイクロクラックを示す。マイクロクラックは 粒界、それも低次Cr炭化物界面で発生する。発生頻度は 比較的小さく、かつ発生領域もかなり不規則であった。 そのため、プロセスゾーンの大きさ、あるいはプロセス ゾーンウエイクの幅を確讃することはできなかった。
上記の結果は、本試料が構造材料セラミックスに要求 される二つの本質的特性を具備することを示した。その 第一は、亀裂の易分岐性ならびにマイクロクラックの発 生である。これは、破壊に際しR-曲線挙動を示す高勒性 セラミックスであることを立証する。現在、本試料に関 して R-曲線は得られていないが、奄裂の分岐形態から推 して、かなり大きい $\mathrm{K}_{\mathrm{R}}$ 值が推測される。第二の点は、常 温破壊の亀裂伝播速度がきわめて達い特性である。その 結果、破壤後に分岐渑裂が多数残存する。これは安定破 壤領域が大きく、そのため破瞔が小規模に抑えられるこ と、換言すれば、Hasselman ${ }^{8)}$ が提唱した損侮抵抗係数が 大きい材料であることを裏付ける現象といえる。さらに、 龟裂伝播速度は高温で一層遅くなるものと期待される。 これは、高温用構造材料セラミックスにおける破譻予知 の可能性を示唆しており、将来セラミックスの信頼性向 上に重要な役割を果すであろう。したがってこの両特性 は、高硬度、易焼結性、易加工性、易接合性などの特長 と相俟って、この種の金属性多元系複合セラミックスの

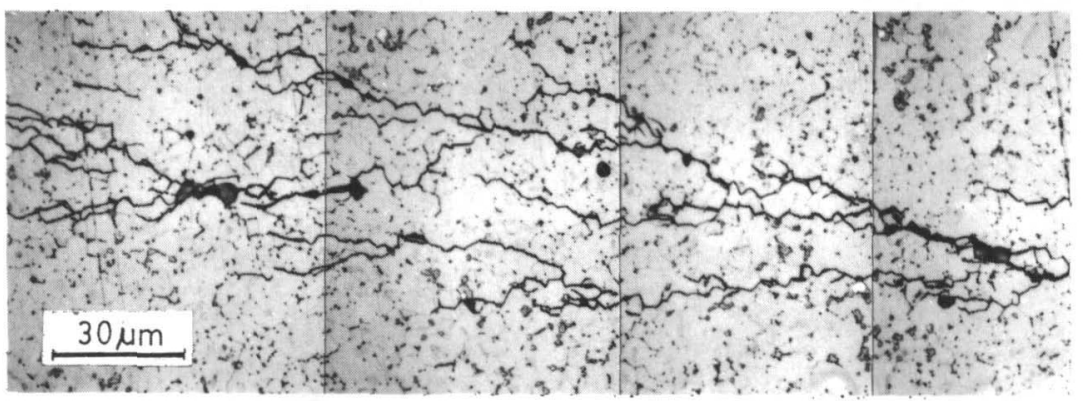

Photo. 7 Branching of cracks observed in specimens sintered at higher temperatures. Deflection of cracks and sub-cracks are also observed.

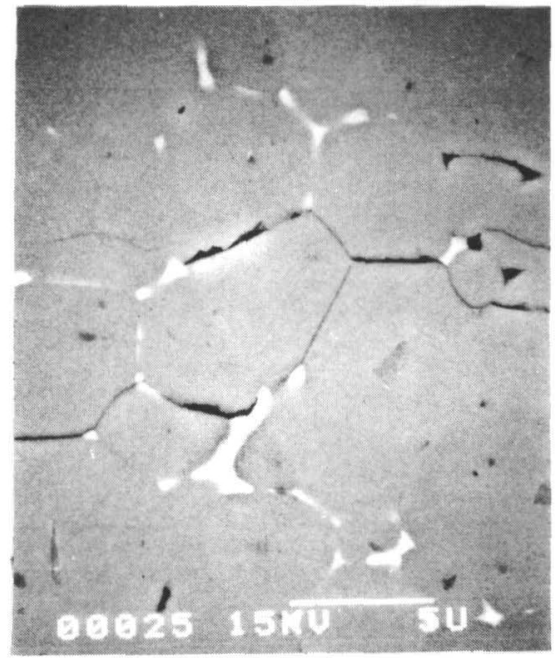

Photo. 8 SEM photograph of the branched crack in the vicinity of the tip.

Crack propagates through intergranular.

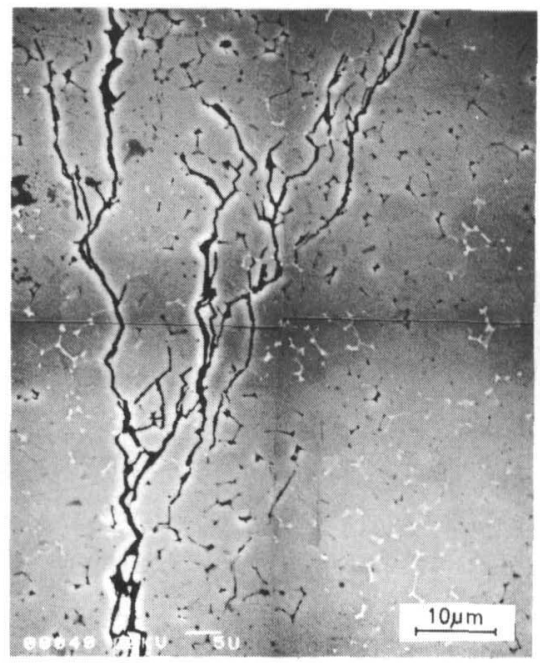

Photo. 9 Microcracks observed in the vicinity of branchings of cracks in the specimens sintered at $1823 \mathrm{~K}$. 
構造材料としての将来性を期待させる重要な特性と言え よう。

\section{IV 考 察}

本項では、本試料の強勒化現象について考察する。各 試片 ${ }^{5)}$ は緱密焼結体であり、かつ、焼結温度に伴う徽構 造变化もきわめて単純化できる。すなわち、1623Kでの完 全絲密化時点で $\mathrm{Mo}_{2} \mathrm{C}$ とTiNとは完全に、また $\mathrm{Cr}_{3} \mathrm{C}_{2}$ も約 85 \%がマトリックス相へ固溶しており、本実験範囲での $\mathrm{Cr}_{3}$ $\mathrm{C}_{2}$---実質的にはCrC---のマトリックスへの固溶は 0.41 mol\%にすぎない。したがって、マトリックスの組成変化 を無視しても、基本的には問題ないと考えられる。これ と関連し、各Cr炭化物の構成比率の変化も僅かである。 完全繳密化時点で金属不純物の固溶・吸収も完了してい る。さらに、本試料の強勒化では熱膨張係数が大きいCr 炭化物の特長が重要な役割を果すが、各 $\mathrm{Cr}$ 炭化物の熟膨 張保数は比較的近似する。すなわち、 $\mathrm{Cr}_{3} \mathrm{C}_{2} 、 \mathrm{Cr}_{7} \mathrm{C}_{3}$ およ び $\mathrm{Cr}_{23} \mathrm{C}_{6}$ の熟膨張係数 $(300 \sim 1270 \mathrm{~K})^{9)}$ はそれそれ 11.7,

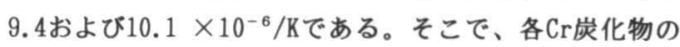
構成比率変化の影響もここでは無視する。したがって、 本実験範囲での微構造変化はマトリックス相とCr炭化物 との粒径および粒形に限定されることになる。以上の前 提に立って、本試料を固溶体相であるマトリックスに $\mathrm{Cr}$ 炭化物が分散粒子として分散する単純な粒子分散型複合 セラミックスとして取り扱い、その強䇝化現象を検討す る。

まず、高勒化について考察する。破壊勒性 $\mathrm{K}_{1 \mathrm{C}}$ は次式で 表される。

$$
\begin{aligned}
& \mathrm{K}_{\mathrm{IC}}=\left(2 \mathrm{E} \gamma_{\mathrm{o}}\right)^{1 / 2} \\
& \text { ここで、 } \\
& \mathrm{E}: \text { ヤング率 } \\
& \gamma_{\mathrm{e}}: \text { 有効破壊エネルギー }
\end{aligned}
$$

E は気孔以外の微構造には不敏感な物質定数である。 したがって本試料における高勒化は、 $\gamma$ 。の増大を意味す る。 $\gamma_{\mathrm{e}}$ は可逆熱力学的表面エネルギー $\gamma_{\mathrm{s}}$ に加えて不可 逆な多くのエネルギー消費を包含するが、これを次式で 総括できる。

$$
\begin{aligned}
& \gamma_{\mathrm{e}}=\left(\gamma_{\mathrm{s}}+\gamma_{\mathrm{P}}+\gamma_{\mathrm{AB}}+\gamma_{\mathrm{D}}+\gamma_{\text {other }}\right) \mu \\
& \text { ここで、 }
\end{aligned}
$$

$\gamma_{\mathrm{p}}$ : 塑性変形ならびに破面上の塑性層形成エネル ギー

$\gamma_{\mathrm{AE}}$ ：亀裂進展に伴了音の発生に消費されるエネル ギー

$\gamma_{\mathrm{D}}$ ：亀裂の運動エネルギー、または振動、光、熟な どとして消費されるェネルギー

$\gamma_{\text {other }}$ ：その他の因子により消費されるエネルギー

$\mu$ : 破面か平坦でないことを補正する係数 セラミックスでは、主として $\gamma_{\text {other }}$ と $\mu$ とが微構造に

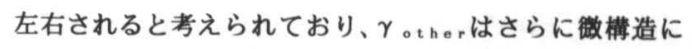
係わる種々の寄与に細分される。

$$
\begin{aligned}
& \gamma_{\mathrm{other}}=\gamma_{\mathrm{po}}+\gamma_{\mathrm{gb}}+\gamma_{\mathrm{mo}}+\gamma_{\mathrm{t}} \\
& \text { ここで、 } \\
& \gamma_{\mathrm{po}}: \text { 気孔の寄与 } \\
& \gamma_{\mathrm{sb}}: \text { 粒界の寄与 } \\
& \gamma_{\mathrm{mo}}: \text { マイクロクラックの寄与 } \\
& \gamma_{\mathrm{t}}: \text { 分散粒子の変態の寄与 }
\end{aligned}
$$

本陚料の場合、 $\gamma_{\mathrm{p}} \mathrm{o} と \gamma_{\mathrm{t}}$ に関しては無関係である。し たがって本試料の高勒化には、粒界とマイクロクラック の寄与が考えられる。

本粒子分散型複合セラミックスにおいて、粒界の寄与 が期待されるエネルギー曼収機構として、亀裂先端と分 散相との相互作用では渑裂のピン止め(pinning) ${ }^{10,11)}$, 湾曲(bowing $)^{12-14)}$, 偏向 ${ }^{15-17)}$ および分岐 ${ }^{18,19)}$ か、ま たプロセスゾーン内での誘起現象ではマイクロクラッキ ング18. 20-24) が挙げられるが、本実験で俥裂のピン止め 現象は観察されなかった。Photo. 10 は粗大な疑集Cr炭 化物を貫通する渑裂伝播の例であるが、このような粗大 粒子でもピン止め現象はほとんど認められなかった。

また、湾曲による吸収エネルギー $\gamma$ 。に関しては、次式 の関係 ${ }^{12)}$ が存在する。

$$
\begin{aligned}
& \gamma_{\mathrm{e}}=\gamma_{\circ}+\mathrm{F}(\mathrm{D}) \mathrm{T} / \mathrm{d} \\
\text { ここで、 } &
\end{aligned}
$$$$
\gamma_{0}: \text { マトリックスの破壊エネルギー }
$$

$\mathrm{T}$ : 線張力

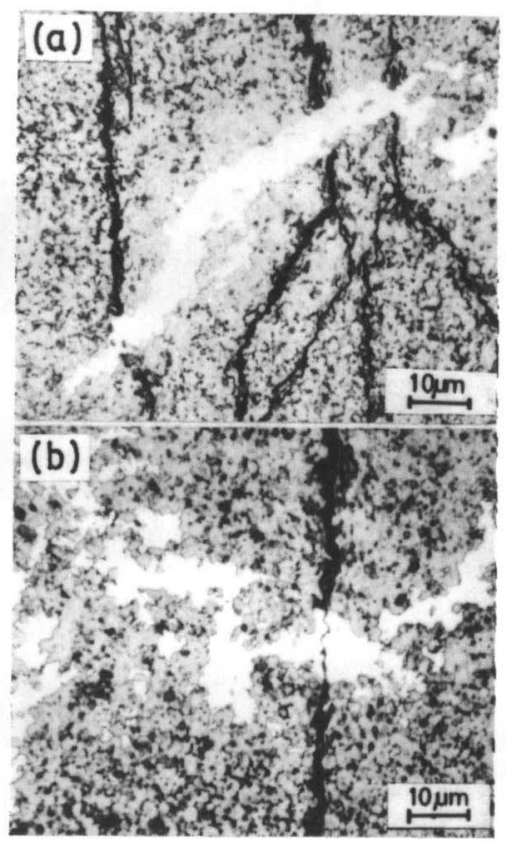

Photo.10 The branched cracks passing through aggregated large grain of chromium carbide without pinning. 
$\mathrm{d}:$ 粒子間距離

$\mathrm{F}(\mathrm{D})$ : ピン止め程度を表す関数

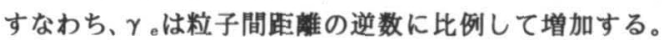
この関係は、粒成長に伴う本試料の高靶化における寄与 を否定する。

Photo.11 は破面の低倍率SEM像である。高温焼結試片 では、微緗な龟裂分㩽に対応した破面上での複雑な山凸 が観察された。これは、(2)式の $\mu$ 值の増大を裏付ける。

以上の考察から、本試料の高靶化は龟裂の分岐、偏向 ならびにマイクロクラッキングを主要な高勒化機構とす るマルチタフニング現象であると結論される。

上記の各エネルギー吸収機構には、マトリックスと分 散相の熟膨張係数の差に起因する粒界徵視応力が密接に 関与する。しかも、一定量の分散粒子を含有する粒子分 散型複合セラミックスにおいて、冷却過程で発生する局 部的な微視応力の大きさは、粒径 ${ }^{25)}$ と温度差に比例す る。さらに、粒形の寄与が付加される。Photo. 12 は粗 大な低次Cr炭化物数集粒子の周辺に冷却過程で発生した 亀裂であるか、Cr炭化物粒形が複雑な場合 (b)、複雑な奄 裂発生が見られる。これは、低次Cr炭化物のマトリック ス相粒界への伸長 ${ }^{5)}$ が龟裂分岐を助長することを示唆す る。したがって、高温焼結ほど上記エネルギー吸収機構 の発生が促進されるものと推考される。ただし、圧痕 亀裂に分岐ならびにマイクロクラックの発生は諗められ ないから、Fig.1 に示した鞄性上昇にこの両破壊エネル ギ一吸収機構の寄与はほとんど含まれないものと考えら れる。

つぎに、高強度化について考察する。表面あるいは内

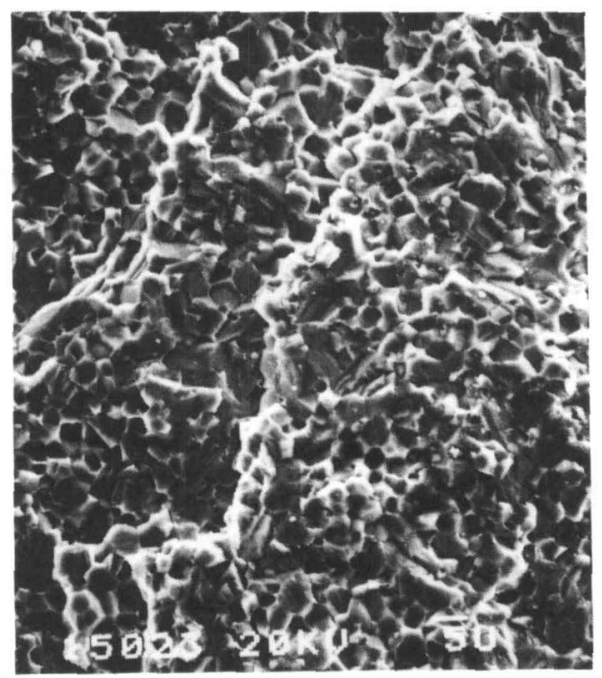

Photo.11 SEM photograph in low magnification of a fracture surface of the ceramic composite sintered at higher temperature. This shows unevenness of the crack surface corresponding to branchings and deflerctions of cracks.
部の微小亀裂の成長による脆性材料の破壤条件は、次式 で表される。

$$
\sigma_{\mathrm{f}}=\mathrm{K}_{\mathrm{I} C} / \mathrm{Y} \cdot \mathrm{C}^{1 / 2}
$$

ここで、

$$
\sigma_{\mathrm{f}}: \text { 破壤強度 }
$$

$\mathrm{K}_{I C}$ : 破壤靶性

C: 不安定破壤が生ずる際の需界奄裂寸法

Y：微小亀裂の形状因子(無次元の定数)

本実験範囲では、Yはほほ一定と考えられる。また、 $\mathrm{K}_{1 \mathrm{C}}$ の変化は既述の通りである。したがって、本試料におけ る基本的な高強度化機構はCの寄与によって決まる。

従来の研究によれば、粒子分散型複合セラミックスに おける強化理論は、Hasselman ${ }^{26)}$ とLange ${ }^{12)}$ との両理論 に大別することができる。前者は分散粒子の粒子間匝離 が製限するため強度が上昇するというものであり、こ の理論では、Cr炭化物の粒子間距離の短縮が前提となる。 しかし、高温焼結に伴う粒成長はこの前提を否定する。 すなわち、本試料における強度上昇にCは寄与していない と考えられる。

したがって本試料の高強度化は、進展する星裂と分散 粒子との相互作用による破壤エネルギーの上昇が高強度 化をもたらすとするLangeの理論、換言すれば、R-曲線挙 動に基づく強度上昇であろうと推考される。既述の抗折 力試験における負荷速度の低下現象は、この強化機構を

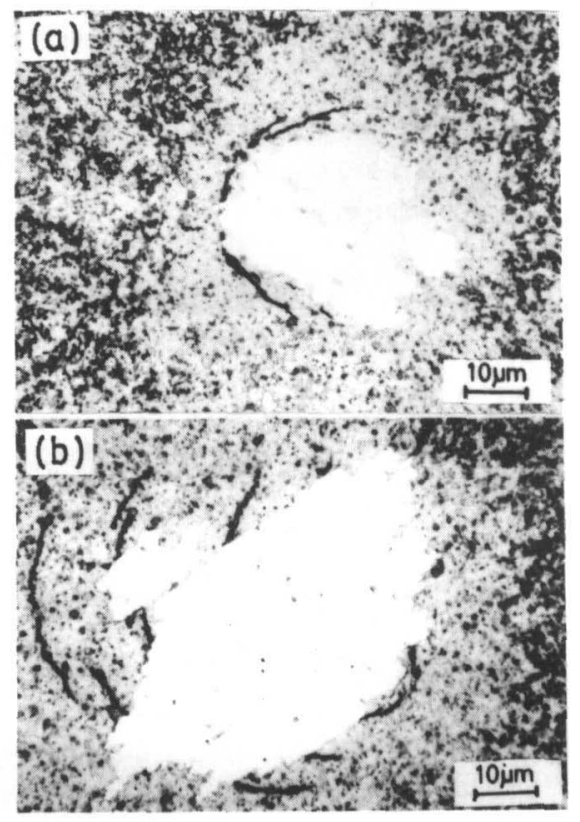

Photo. 12 Cracks around the aggregated large grain of chromium carbide, occurred in cooling due to the mismatch of thermal expansion coefficient between matrix and the dispersed phase. Irregular shaped grain (b) facilitates the occurrence of many cracks. 
裏付ける。

\section{$\mathrm{V}$ 結 論}

$\mathrm{TiC}-\mathrm{Cr}_{3} \mathrm{C}_{2}$ 系に対する $\mathrm{Ho}_{2} \mathrm{C}$ と TiNとの同時添加によって、 1623K焼結での完全密化が実現した。本研究では、この 易焼結性T iC-TiN- $\mathrm{Mo}_{2} \mathrm{C}-\mathrm{Cr}_{3} \mathrm{C}_{2}$ 多元系複合セラミックスの 程密偾結体における強鞄化現象を短結温度との関係から 娭討し、以下の結果を得た。

(1)本多元系複合セラミックスは、絊密化後の高温焼結 で粒成長を伴って强勒化する。すなわち、1823K焼結で抗 折力は約 $180 \mathrm{MPa}$ 上昇し、784MPaに達した。これは、 $\mathrm{TiC}-$ $\mathrm{Cr}_{3} \mathrm{C}_{2}$ 系に比ペ、約 $300 \mathrm{MPa}$ 強度改善に相当する。また、

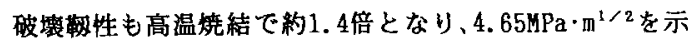
した。

（2）硬度も高温枿結で上昇し、1823K焼結でHv:24.0GPa に達した。これは、切削工具用セラミックスとしてきわ めて優れた高硬度である。

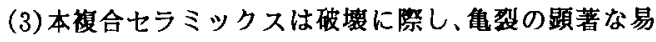
分吱性を有することが確認された。これは、R-曲線挙動 を示す強䩒性セラミックスであることを立証する。しか も、亀裂伝播速度が遅く、破断後に行吱龟裂が多数残存 する。この両特性は、この種の金属性多元系複合セラミ ックスの将来性を期待させる重要な特性である。

(4)残存分岐重裂の形態から、本複合セラミックスの高 靱化は隹裂の分蚑、偏向およびマイクロクラッキングを

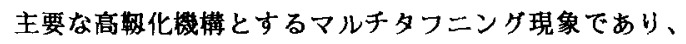
強度の上界はR-曲線挙動に基つくものと推論された。た だし、本奏験結果が示した破壤靶性の上界には、釷裂分 岐ならびにマイクロクラッキングの寄与はほとんど含ま れないものと考えられる。

\section{文献}

1）蜂須賀：粉体6L鿟末治金，37[6](1990),861.

2) D.Das, K.S.Mazdiyasni and H.A. Lippsitt: J. Amer. Cer. Soc. , 65 (1982), 104.

3) A.P.Katz, H.A.Lippsitt, T.Mah and M.G. Mendiratta: J.Matter.Sci., 18(1983), 1983.
4）蜂須賀：粉体的枌末冶金，37[4](1990)，556.

5）蜂須賀：粉体bL粉末治金，(投稿中）

6) A.G. Evans and E. A. Charles: J.Amer. Cer, Soc. , 59 (1976), 371.

7) 西田, 西川：䉆業協会誌, 89(1981), 544.

8) D. P. H. Hasselman: J. Amer. Cer. Soc. , 46 (1963), 535.

9）高融点化合物便覧，日 - ソ通信社, 和歌山(1977).

10) D. J.Green: J. Amer. Cer. Soc., 66 (1983), C5.

11) R. Morena, K. Ni ihara and D. P. Hasselman: J. Amer. Cer. Soc., 66(1983), 221.

12) F.F. Lange: Phil.Mag., 22(1970), 983.

13) C.N.Ahlquist: Acta Metall., 23(1975), 239.

14) D.G.Green, P.S. Nicholson and J.D.Embury: J. Mater. Sci., 14(1979), 1413.

15) K.T. Faber and A.G. Evans: Acta Meta 11., 31(1983) , 577.

16) K.T.Faber and A.G. Evans: J.Amer. Cer.Soc., 66 (1983), C94.

17）鈴木：第4回高温材料基礎討諭会講演要旨集 (1984) , 31.

18) R.W.Rice, K. R. Mckinney, C.C.Wu, S.W. Freiman and W.J.M. Donough: J. Mater. Sci., 20 (1985), 1392.

19) F.F.Lange: Fracture Mechanics of Ceramics. vol.2. R. C. Bradt Eds. Plenum Press. (1974), 599.

20) F. F. Lange: J. Mater. Sci., 10(1975), 314.

21) N.Claussen: J.Amer. Cer. Soc., 59(1976) 49.

22) N.Claussen, J.Steeb and R.F.Pabst: Amer.Cer. Soc. Bul 1. , 56 (1977), 559.

23) D.J.Green : J.Amer. Cer. Soc. , 64(1981), 138.

24）岡田,広崎：第5回高温材料基磁討論会講演要旨集 (1985), 17 .

25) A. G.Evans: J.Amer. Cer. Soc., 65(1982), 127.

26) D.P.H. Hasselman and R.M. Fulrath : J.Amer.Cer. Soc. , 49(1966), 68 . 